\title{
Analysis of Commercial Assays for the Detection of SARS-CoV-2 Antibodies or Antigens
}

\author{
John M. González\#, William J. Shelton*, Manuel Díaz-Vallejo*, Victoria E. Rodriguez-Castellanos*, \\ Juan Diego H. Zuluaga*, Diego F. Chamorro*, Daniel Arroyo-Ariza*
}

Biomedical Sciences Group, School of Medicine, Universidad de los Andes, Bogotá, DC, Colombia

Email: "johgonza@uniandes.edu.co

How to cite this paper: González, J.M. Shelton, W.J., Díaz-Vallejo, M., RodriguezCastellanos, V.E., Zuluaga, J.D.H., Chamorro, D.F. and Arroyo-Ariza, D. (2020) Analysis of commercial assays for the detection of SARS-CoV-2 antibodies or antigens. Open Journal of Immunology, 10, 21-35. https://doi.org/10.4236/oji.2020.102003

Received: April 27, 2020

Accepted: June 15, 2020

Published: June 18, 2020

Copyright $\odot 2020$ by author(s) and Scientific Research Publishing Inc. This work is licensed under the Creative Commons Attribution International License (CC BY 4.0).

http://creativecommons.org/licenses/by/4.0/

\section{(c) (i) Open Access}

\begin{abstract}
Background: COVID-19 produced by SARS-CoV-2 infection has spread worldwide. There is a growing need for immunological assays to detect viral specific antibodies or viral antigen. Current standard of diagnosis is reverse-transcriptase polymerase chain reaction (RT-PCR) in nasopharyngeal swabs. However, serological tests can be used to determine previous exposure to the virus and complement the diagnosis. IgM and IgG SARS-CoV-2 specific antibodies can be detected as early as one week after infection and assays can be useful to test large groups of individuals. This work revised the available information concerning assays that detect antibodies and antigens for SARS-CoV-2. Methods: Three sources of information were used: technical data sheets (TDS), web pages of the company's products, and published articles in Pubmed with reference to the use of diagnostic kits. All the information was revised until April $5^{\text {th }}$ 2020. Results: There were 226 tests coming from 20 countries, mainly from China. TDS were found only in $50(22.1 \%)$. Most assays detect specific antibodies (n 180) based on immunochromatography methods (n 110) and use blood-derived samples (n 105). Assays for antibodies detection measured mainly $\operatorname{IgM} / \operatorname{IgG}(\mathrm{n} 112)$ and the most common procedure time was $<20 \mathrm{~min}$ ( $\mathrm{n} 83$ ). Internal control referred as sensitivity and specificity was found only in $18.6 \%$ ( $\mathrm{n} 42$ ) of the assays. The majority of the tests are currently for in vitro diagnosis (IVD). A total 165 articles were found on PubMed, 15 were included and only 4 used the commercial kits reviewed. Conclusions: Due to the urgency of producing diagnostic tests for SARS-CoV-2, there is a broad offer of kits. Many tests need additional information for their application. The data collected may be useful in the selection of assays, but more and higher quality information is needed.
\end{abstract}

\section{Keywords}

Antibody, Antigen, Coronavirus, Immunoassay, SARS

^These authors contributed equally to this work. 


\section{Introduction}

Nidoviruses are positive-sense single-stranded RNA viruses that infect a large number of vertebrates. Within these is the family of coronaviruses, which has four groups, that caused three epidemic outbreaks in recent decades [1]. Coronaviruses were described as causing common respiratory symptoms in the 1960's [2]. They may be responsible for between $7 \%$ and $15 \%$ of uncomplicated upper respiratory infections [3]. SARS (severe acute respiratory syndrome) in 2002, from China, was the first report of a coronavirus outbreak with a mortality around $10 \%$. The virus was presumably transmitted to humans by a mammal (civet cat), probably derived from bats. The second outbreak was MERS (Middle East respiratory syndrome), originated in Saudi Arabia, transmitted by camels, but also probably derived from bats; with a mortality close to $40 \%$ [1]. Now, we have a third epidemic, the coronavirus (CoV) SARS-CoV-2, which produces COVID-19 (coronavirus disease 2019). The outbreak began in the Wuhan province in China, but has now turned into a pandemic. The sequence of the virus genome isolated from patients is similar to a bat virus [4]. In China, the infection produced mild respiratory symptoms in about $80 \%$ of those infected, however, $5 \%$ were admitted to the Intensive Care Unit (ICU), $2.3 \%$ received mechanical ventilation and the mortality rate was $1.3 \%$ [5]. The rapid case growth around the world means that in a short time the health systems could saturate rapidly [6]. The current standard assay for COVID-19 diagnosis is the detection of viral RNA in nasopharyngeal swabs using reverse-transcriptase polymerase chain reaction (RT-PCR) [7]. Rapid and simple immunoassay tests have been developed to detect viral antigen or antibodies against the SARS-CoV-2 virus in human blood even within 15 minutes. Antibody response can be detected as early as 5 days post-infection [8] and the antibody-secreting cells peak around day 7 - 8 post-infection [9] [10]. One of the first peer reviewed studies of this kind of assays showed a sensitivity of $88.66 \%$ and a specificity of $90.63 \%$ in 397 patients with SARS-CoV-2 confirmed by PCR [11]. There are currently more than 200 immunoassays for SARS-CoV-2 to detect antigens or specific antibodies [12]. The goal of this study is to carry out a comprehensive review of the wide offer of serological kits to detect SARS-CoV-2 antigen or antibodies, in order to help institutions and policymakers define the best option for massive testing. There is an urgent need for rapid serological assays for SARS-CoV-2 that will be a useful tool for public health in the upcoming days.

\section{Methods}

\subsection{Test Search}

We conducted web searches for pages listing serology assays for SARS-CoV-2. Descriptive information from each assay was obtained from technical data sheets (TDS) or their respective company web page. Variables obtained were: country of origin, type of immuno-assay, procedure time, sample type, fixed antibody for direct assays, fixed antigen and antibody isotype for indirect assays, sensitivity, 
specificity, current regulatory status and published studies. We used not reported (N/R) to specify when information about a variable was not found; and N/A when a variable did not apply.

\subsection{Literature Search}

A search was conducted using Pubmed based on the PRISMA guidelines (http://www.prisma-statement.org/) for articles describing studies of serology with human samples for SARS-CoV-2. For our search strategy we used the terms: Human + (serology OR antibodies) + (nCoV OR SARS-CoV-2 OR COVID-19) and also (serology OR antibodies) + (nCoV OR SARS-CoV-2 OR COVID-19). Inclusion criteria incorporated articles published in English that involved studies with serological tests for SARS-CoV-2 diagnosis. The following articles were rejected: all those that did not contain serological assays for SARS-CoV-2 diagnosis; studies in another language different than English and studies that were not related to SARS-CoV-2. We examined the articles, looking for ones that mentioned the use of commercial antigen or antibody detection kits. Data was obtained until April $5^{\text {th }} 2020$.

\subsection{Data Analysis and Report}

Information was stored in an Excel file (Microsoft, Redmond, WA). Data was randomly chosen to be verified by two authors. Information was presented as percentages and means. No statistical analysis was applied.

\subsection{Ethics Statement}

There were no patients or clinical data involved in the development of this study, thus no approval by any Institutional Review Board was needed.

\section{Results}

\subsection{Tests' Characteristics}

We scanned the internet for web pages listing immunoassays for SARS-CoV-2 until April 5th of 2020, and four were used: https://www.finddx.org/ (n 213), https://www.modernhealthcare.com/ (n 99), https://www.fda.gov/ (n 54) and https://www.minsal.cl/ (n 12), Supplementary Table S1. The last web page was included because it had information about assays developed in South America, not found in the other lists. Information about kits and companies was crossed to complete or eliminate entries. We used companies' web pages and technical data sheets (TDS), the official document provided by the manufacturer including specific characteristics, instructions for use, clinical and analytical performance. We found a total of 226 immunoassays from 20 different countries, $80.1 \%$ came from 4 countries, China, USA, South Korea and Germany. These countries represent $48.7 \%, 21.7 \%, 9.7 \%$ and $3.5 \%$ of the assays, respectively. TDSs were found in $22.1 \%$ of assays. Assays were divided in antigen detection (direct) or antibody detection (indirect), according to each TDS. When the TDS 
was not available (n 176), the assay type was assigned according to the description of the tests' name. From the reported (n 219), 82.2\% were indirect and $17.8 \%$ were direct assays. Samples used to carry out the tests were categorized in: blood-derived (blood, serum, plasma) and naso-oropharyngeal swab and other fluids (oropharyngeal swab, bronchoalveolar lavage or sputum). For 112 of the assays, the sample type was not identified and from the reported, $92.1 \%$ use blood-derived samples, and only 7.9\% swabbing samples. All of the samples obtained from naso-oropharyngeal swabs were for direct assays.

From the antigen assays (direct n 39), only two reported the specific monoclonal antibodies fixed to the plate, against viral nucleocapsid (N) protein. From the antibody assays (indirect n 180) 25 reported the antigen used for antibody detection: 2 whole viral antigen and 23 recombinant proteins including the spike (S) protein (n 3), nucleocapsid (n 1) and recombinant unspecified viral antigen (n 19). Only 172 assays reported the method used for evaluation. Most of these assays were based on immunochromatography (63.6\%), followed by ELISA (23.1\%) and different methods for fluorescence detection (6.4\%). For the tests that describe the strategy of result interpretation (n 166), as most of the assays are based on immunochromatography, results are visualized as bands in $65 \%$ and $35 \%$ are automated. There are also techniques based on chemiluminescence, immunoturbidimetry and bioelectronic detection. Of the total group of antibody assays, some analyzed a unique antibody isotype: IgA one assay (0.5\%), IgG 22 assays (11.7\%) and IgM 24 assays (12.8\%); others analyzed two isotypes simultaneously: 112 assays detected $\operatorname{IgM} / \operatorname{IgG}(59.6 \%), 2 \operatorname{IgM} / \operatorname{IgA}(1.1 \%)$ and 2 measured three isotypes, $\operatorname{IgA} / \operatorname{IgG} / \operatorname{IgM}(1.1 \%)$. A total of 5 assays (2.7\%) reported measuring total antibodies, Table 1. Procedure time was not found in 124 (55\%) and $102(45 \%)$ reported the specific time. Of these, 43 assays are done in $10 \mathrm{~min}$ or less, 40 between 10 to $20 \mathrm{~min}$ (42.2\% and 39.2\%, respectively), 4 between 20 to $30 \mathrm{~min}(3.9 \%)$, one between $30 \mathrm{~min}$ and 1 hour $(1 \%)$, and 14 take more than an hour (13.7\%), some of them reaching even two hours.

A total of $18.6 \%$ of the assays reported internal validation, defined here as the data either found in the TDS or provided by the manufacturer web page. The number of assays that reported sensitivity or specificity was 41 (18.1\%) and 42 (18.6\%) respectively. The sensitivity of the assays ranged between $45 \%$ and $100 \%$, Table 2 . On the other hand, the specificity of the assays ranged between $90.3 \%$ and $100 \%$, Table 3 . Only 33 (14.1\%) provided the number of individuals evaluated for the sensitivity and specificity analysis. The average number of individuals tested was 274, including 12 with less than 100 individuals and 1 kit with more than 1000 individuals tested. The average percentage of infected individuals was $36.1 \%$ of the tested individuals. More specific data on sensitivity, specificity and the number of people tested can be found in Supplementary Table S2. Regarding the intent to use and regulatory status no current label requirement was found for 46 assays (20.4\%). From the reported, $113(62.8 \%)$ qualified for in-vitro diagnostics (IVD), 37 (20.6\%) for research use only (RUO), 
Table 1. Antibody isotypes measured by indirect serological assays.

\begin{tabular}{ccc}
\hline Antibody isotype & $\mathrm{n}$ & Percentage (\%) \\
\hline Total antibodies & 5 & 2.7 \\
IgA & 1 & 0.5 \\
IgG & 22 & 11.7 \\
IgM & 24 & 12.8 \\
IgA/IgM & 2 & 1.1 \\
IgM/IgG & 112 & 59.6 \\
IgA/IgG/IgM & 2 & 1.1 \\
N/R & 20 & 10.6 \\
Total & 188 & 100 \\
\hline
\end{tabular}

N/R: Not reported.

Table 2. Reported sensitivity of the serological assays (internal validation).

\begin{tabular}{cccc}
\hline Sensitivity $\%$ & IgM & IgG & IgM + IgG \\
\hline$\leq 80 \%$ & $6(23.1 \%)$ & $2(7.7 \%)$ & $1(5.2 \%)$ \\
$80 \%-90 \%$ & $15(57.7 \%)$ & $6(23.1 \%)$ & $3(15.8 \%)$ \\
$90 \%-95 \%$ & $3(11.5 \%)$ & $4(15.4 \%)$ & $9(47.4 \%)$ \\
$95 \%-97.5 \%$ & $1(3.8 \%)$ & $4(15.4 \%)$ & $3(15.8 \%)$ \\
$\geq 97.5 \%$ & $1(3.8 \%)$ & $10(38.5 \%)$ & $3(15.8 \%)$ \\
Total & $26(100 \%)$ & $26(100 \%)$ & $19(100 \%)$ \\
\hline
\end{tabular}

Table 3. Reported specificity of the serological assays (internal validation).

\begin{tabular}{cccc}
\hline Specificity $\%$ & $\operatorname{IgM}$ & $\operatorname{IgG}$ & $\operatorname{IgM}+\operatorname{IgG}$ \\
\hline$\leq 90 \%$ & $0(0 \%)$ & $0(0 \%)$ & $0(0 \%)$ \\
$90 \%-95 \%$ & $1(4 \%)$ & $1(4.2 \%)$ & $3(16.7 \%)$ \\
$95 \%-97.5 \%$ & $7(28 \%)$ & $4(16.7 \%)$ & $7(38.9 \%)$ \\
$\geq 97.5 \%$ & $17(68 \%)$ & $19(79.2 \%)$ & $8(44.4 \%)$ \\
Total & $25(100 \%)$ & $24(100 \%)$ & $18(100 \%)$ \\
\hline
\end{tabular}

$29(16.1 \%)$ were in development and $1(0.6 \%)$ was classified as IVD/RUO. Only 17 have received regulatory certification (of emergency use) issued by a health authority. The number of assays approved for use in the following countries is; Australia (TGA) 3, Brazil (ANVISA) 6, China (NMPA) 4, European Community (CE) 6, India (ICMR) 1, Singapore (HSA) 2 and USA (FDA) 1; some assays may be certified in more than one country. Additionally, the FDA has received documentation to request approval for 56 assays.

\subsection{Literature Review}

We reviewed the literature published until April $5^{\text {th }} 2020$, where they used the 
serological assays listed. We found 165 articles, 95 duplicates were removed which left 70 articles for screening and 15 were selected of which only 4 used the listed kits [9] [11] [13] [14]. PRISMA summary is shown in Supplementary Figure S1.

\section{Discussion}

The current standard for COVID-19 diagnosis is the amplification of viral RNA by RT-PCR. However, this technique requires special equipment and trained individuals [7]. Also, detection of the virus is dependent on the sample origin and time of sampling [15] [16]. Detection of virus specific SARS-CoV-2 antibodies could help determine the exposure of a large population to the virus [5] [8] [9] [10]. In infected individuals, antibody detection by ELISA using nucleocapsid protein as antigen was identified at day 5 for IgM and at day 14 for IgG [17]. IgM antibodies are known to be produced early during a viral infection, followed by the presence of IgG antibodies, which have a longer lifespan and are responsible for the memory response [18]. Besides diagnosing the disease, it is important to determine the immune status of the individual against the SARS-CoV-2 using detection of specific antibodies. Now, there is an offer of more than 200 diagnostic assays that detect viral antigen or specific antibodies, all of them in different stages of validation.

Initial reports of the new SARS-CoV-2 causing acute respiratory distress syndrome came up in Wuhan, China. Since then, several assays have been developed in order to improve the diagnosis, most of them from China [4] [19]. As expected, most of the available assays detect antibodies using blood-derived samples. Although RT-PCR is considered the most sensitive detection method in respiratory fluid samples, it increases the risk of contamination of healthcare workers [20]. Blood-derived samples are easier to obtain, and compared to RT-PCR, serological assays are faster, require less training and less equipment, so they can be used in almost any setting [11]. The most common method behind is immunochromatography [21]. These assays have a long shelf-life, do not require refrigeration and visual results exclude the need for additional equipment compared with other methods such as ELISA [22]. Antigens used for detection are very important; the genome of SARS-CoV-2 codifies for several structural proteins, including the spike (S), membrane (M), envelope (E), and nucleocapsid $(\mathrm{N})$ proteins [23]. The most common antigens used for indirect assays are the recombinant spike and nucleocapsid proteins [16] [17]. The S protein contains the domain that allows attachment to the human host cells [24], and the nucleocapsid protein is one of the major structural components involved in many processes of the virus, including viral replication, transcription, and assembly [18]. Interestingly, there is a $90.5 \%$ homology among nucleocapsid proteins of SARS-CoV-1 and SARS-CoV-2 [17]. Also SARS-CoV-2 showed a homology of about $85 \%$ with a coronavirus isolated from bats [4] [16].

Assay specificity and sensitivity are key for determining the role of these tests 
in diagnosis and public health programs [25]. Unfortunately, only a minority of the assays present this information, maybe due to the short development time. However, most of them present a sensitivity and specificity over $90 \%$, but with a low number of infected individuals. Nonetheless, some have sensibility as low as $45 \%$. Patients with RT-PCR confirmed disease began developing specific viral antibodies around 7 days from disease onset [8] [9]. Some studies showed that IgM seroconversion occurs earlier in the course of illness, followed by IgG seroconversion [8] [9] [11], while others describe a simultaneous seroconversion [26]. All studies agree that the seroconversion rate for IgG and IgM increases with time [8] [9] [26]. The detection rate of molecular based methods decreased to as low as $45 \%$ in the first 2 weeks [9] [15] [27], while antibodies were detected in $100 \%$ of the patients after a month of disease onset [8] [9] [26]. The latter shows that the sensitivity of each immunoassay is variable depending on the time of onset, with more positive results given in a later time of the disease [17]. Most tests evaluate the presence of IgG and IgM simultaneously. The dual detection of IgG-IgM improves the sensitivity in comparison with individual IgG or IgM antibody assays [11], suggesting a possible improvement in infection detection. Additionally, the different samples that can be used for serological diagnosis offer more consistent results. No significant differences were found when using samples from whole blood, serum or plasma [11]. This is opposed to the great variability from samples used in viral RNA detection (blood, sputum, naso/oropharyngeal swabs, anal swabs and bronchoalveolar lavage) [8] [15] [27] [28]. In terms of efficiency, serological assays have a shorter procedure time compared to molecular diagnostic methods, which means greater testing capacity. RT-PCR and antibody assays have their own advantages, the combination of both can provide more accuracy to the initial diagnosis of SARS-CoV-2 infection [11] [20]. Apart from this, current label requirements showed that most of the offered immunoassays (50\%) are intended for in-vitro diagnosis and this application represents the usefulness in a clinical environment. Limitations to our study include the lack of support by literature and/or certification by government regulation agencies of the majority of the tests that we found. It is worth mentioning that at the time of this review only few months had passed since the spread of the virus worldwide so, fewer studies and tests were available compared to a more advanced pandemic. Nevertheless, we consider the information found was the best obtainable evidence at the time of the review.

At this point of the pandemic, it would be difficult to suggest which assays are the best for clinical application. However, the information here presented sheds light into the large number of assays available, and the number increases day by day, so it has to be analyzed carefully. We suggest that researchers and policymakers focus on the tests with the most information available, such as a rigorous internal validation data and well-defined TDS. More research is needed, especially studies that compare between different assays; which provide more accurate information than studies testing assays individually [29]. Yet, the initial data looks promising and immunoassays could help screen larger populations in less 
time, increasing the detection rate and increasing the testing capacity; which is needed to decrease the SARS-CoV-2 spread. Recent studies show that convalescent patients have high levels of SARS-CoV-2 neutralizing antibodies (NAbs), which increased with patients' age [30]. Interestingly, transfusion of convalescent plasma obtained from COVID-19 cases, improved clinical outcomes of patients with severe disease [31]; thus, suggesting that the antibodies produced by COVID-19 patients during the infection have a posterior protective effect. Large serological studies to detect virus-specific antibodies will be needed to determine the infected asymptomatic population and also could help to suspend social isolation in seropositive individuals.

\section{Acknowledgements}

The authors want to thank Manuel Franco MD, PhD from Pontificia Universidad Javeriana, Bogotá DC, Colombia for critical revision of the manuscript.

\section{Conflicts of Interest}

The authors declare no conflicts of interest regarding the publication of this paper.

\section{References}

[1] Cheng, V.C.C., Lau, S.K.P., Woo, P.C.Y. and Kwok, Y.Y. (2007) Severe Acute Respiratory Syndrome Coronavirus as an Agent of Emerging and Reemerging Infection. Clinical Microbiology Reviews, 20, 660-694. https://doi.org/10.1128/CMR.00023-07

[2] Tyrrell, D.A.J. and Bynoe, M.L. (1965) Cultivation of a Novel Type of Common-Cold Virus in Organ Cultures. British Medical Journal, 1, 1467-1470. https://doi.org/10.1136/bmj.1.5448.1467

[3] Mäkelä, M.J., Puhakka, T., Ruuskanen, O., Leinonen, M., Saikku, P., Kimpimäki, M., et al. (1998) Viruses and Bacteria in the Etiology of the Common Cold. Journal of Clinical Microbiology, 36, 539-542. https://doi.org/10.1128/JCM.36.2.539-542.1998

[4] Zhou, P., Yang, X.L., Wang, X.G., Hu, B., Zhang, L., Zhang, W., et al. (2020) A Pneumonia Outbreak Associated with a New Coronavirus of Probable Bat Origin. Nature, 579, 270-273. https://doi.org/10.1038/s41586-020-2012-7

[5] Guan, W., Ni, Z., Hu, Y., Liang, W., Ou, C., He, J., et al. (2020) Clinical Characteristics of Coronavirus Disease 2019 in China. The New England Journal of Medicine, 382, 1708-1720. https://doi.org/10.1101/2020.02.06.20020974

[6] Livingston, E. and Bucher, K. (2020) Coronavirus Disease 2019 (COVID-19) in Italy. JAMA, 323, 1335. https://doi.org/10.1001/jama.2020.4344

[7] Corman, V.M., Landt, O., Kaiser, M., Molenkamp, R., Meijer, A., Chu, D.K., et al. (2020) Detection of 2019-nCoV by RT-PCR. Eurosurveillance, 25, 1. https://doi.org/10.2807/1560-7917.ES.2020.25.3.2000045

[8] Zhang, W., Du, R.H., Li, B., Zheng, X.S., Yang, X.L., Hu, B., et al. (2020) Molecular and Serological Investigation of 2019-nCoV Infected Patients: Implication of Multiple Shedding Routes. Emerging Microbes \& Infections, 9, 386-389. https://doi.org/10.1080/22221751.2020.1729071 
[9] Zhao, J., Yuan, Q., Wang, H., Liu, W., Liao, X., Su, Y., et al. (2020) Antibody Responses to SARS-CoV-2 in Patients of Novel Coronavirus Disease 2019. Clinical Infectious Diseases, ciaa344.

[10] Thevarajan, I., Nguyen, T.H.O., Koutsakos, M., Druce, J., Caly, L., Van de Sandt, C.E., et al. (2020) Breadth of Concomitant Immune Responses Prior to Patient Recovery: A Case Report of Non-Severe COVID-19. Nature Medicine, 26, 453-455. https://doi.org/10.1038/s41591-020-0819-2

[11] Li, Z., Yi, Y., Luo, X., Xiong, N., Liu, Y., Li, S., et al. (2020) Development and Clinical Application of a Rapid IgM-IgG Combined Antibody Test for SARS-CoV-2 Infection Diagnosis. Journal of Medical Virology. https://doi.org/10.1002/jmv.25727

[12] FIND Evaluation Update: SARS-CoV-2 Immunoassays FIND. https://www.finddx.org/covid-19/sarscov2-eval-immuno

[13] Zeng, H., Xu, C., Fan, J., Tang, Y., Deng, Q., Zhang, W., et al. (2020) Antibodies in Infants Born to Mothers with COVID-19 Pneumonia. JAMA. https://doi.org/10.1001/jama.2020.4861

[14] Lee, N.Y., Li, C.W., Tsai, H.P., Chen, P.L., Syue, L.S., Li, M.C., et al. (2020) A Case of COVID-19 and Pneumonia Returning from Macau in Taiwan: Clinical Course and Anti-SARS-CoV-2 IgG Dynamic. Journal of Microbiology, Immunology and Infection. https://doi.org/10.1016/j.jmii.2020.03.003

[15] Wang, W., Xu, Y., Gao, R., Lu, R., Han, K., Wu, G., et al. (2020) Detection of SARS-CoV-2 in Different Types of Clinical Specimens. JAMA.

https://doi.org/10.1001/jama.2020.3786

[16] To, K.K.W., Tsang, O.T.Y., Leung, W.S., Tam, A.R., Wu, T.C., Lung, D.C., et al. (2020) Temporal Profiles of Viral Load in Posterior Oropharyngeal Saliva Samples and Serum Antibody Responses during Infection by SARS-CoV-2: An Observational Cohort Study. The Lancet Infectious Diseases, 20, 565-574. https://doi.org/10.1016/S1473-3099(20)30196-1

[17] Guo, L., Ren, L., Yang, S., Xiao, M., Chang, D., Yang, F., et al. (2020) Profiling Early Humoral Response to Diagnose Novel Coronavirus Disease (COVID-19). Clinical Infectious Diseases.

[18] Woo, P.C.Y., Lau, S.K.P., Wong, B.H.L., Chan, K.H., Chu, C.M., Tsoi, H.W., et al. (2004) Longitudinal Profile of Immunoglobulin G (IgG), IgM, and IgA Antibodies against the Severe Acute Respiratory Syndrome (SARS) Coronavirus Nucleocapsid Protein in Patients with Pneumonia Due to the SARS Coronavirus. Clinical and Diagnostic Laboratory Immunology, 11, 665-668.

https://doi.org/10.1128/CDLI.11.4.665-668.2004

[19] Zhu, N., Zhang, D., Wang, W., Li, X., Yang, B., Song, J., et al. (2020) A Novel Coronavirus from Patients with Pneumonia in China, 2019. The New England Journal of Medicine, 382, 727-733. https://doi.org/10.1056/NEJMoa2001017

[20] Loeffelholz, M.J. and Tangm, Y.W. (2020) Laboratory Diagnosis of Emerging Human Coronavirus Infections-The State of the Art. Emerging Microbes \& Infections, 9, 747-756. https://doi.org/10.1080/22221751.2020.1745095

[21] Anfossi, L., Di Nardo, F., Cavalera, S., Giovannoli, C. and Baggiani, C. (2018) Multiplex Lateral Flow Immunoassay: An Overview of Strategies towards High-Throughput Point-of-Need Testing. Biosensors, 9, E2. https://doi.org/10.20944/preprints201811.0405.v1

[22] Koczula, K.M. and Gallotta, A. (2016) Lateral Flow Assays. Essays in Biochemistry, 60, 111-120. https://doi.org/10.1042/EBC20150012

[23] Lu, R., Zhao, X., Li, J., Niu, P., Yang, B., Wu, H., et al. (2020) Genomic Characteri- 
sation and Epidemiology of 2019 Novel Coronavirus: Implications for Virus Origins and Receptor Binding. The Lancet, 395, 565-574.

https://doi.org/10.1016/S0140-6736(20)30251-8

[24] Wan, Y., Shangm, J., Grahamm, R., Baricm, R.S. and Li, F. (2020) Receptor Recognition by the Novel Coronavirus from Wuhan: An Analysis Based on Decade-Long Structural Studies of SARS Coronavirus. Journal of Virology, 94, 1-9. https://doi.org/10.1128/JVI.00127-20

[25] Leeflang, M.M.G. (2014) Systematic Reviews and Meta-Analyses of Diagnostic Test Accuracy. Clinical Microbiology and Infection, 20, 105-113. https://doi.org/10.1111/1469-0691.12474

[26] Hsueh, P.R., Huang, L.M., Chen, P.J., Kao, C.L. and Yang, P.C. (2004) Chronological Evolution of IgM, IgA, IgG and Neutralisation Antibodies after Infection with SARS-Associated Coronavirus. Clinical Microbiology and Infection, 10, 1062-1066. https://doi.org/10.1111/j.1469-0691.2004.01009.x

[27] Yang, Y., Yang, M., Shen, C., Wang, F., Yuan, J., Li, J., et al. (2020) Evaluating the Accuracy of Different Respiratory Specimens in the Laboratory Diagnosis and Monitoring the Viral Shedding of 2019-nCoV Infections.

https://doi.org/10.1101/2020.02.11.20021493

[28] Liu, W., Liu, L., Kou, G., Zheng, Y., Ding, Y., Ni, W., et al. (2020) Evaluation of Nucleocapsid and Spike Protein-Based ELISAs for Detecting Antibodies against SARS-CoV-2. Journal of Clinical Microbiology. https://doi.org/10.1101/2020.03.16.20035014

[29] Takwoingi, Y., Leeflang, M.M.G. and Deeks, J.J. (2013) Empirical Evidence of the Importance of Comparative Studies of Diagnostic Test Accuracy. Annals of Internal Medicine, 158, 544-554. https://doi.org/10.7326/0003-4819-158-7-201304020-00006

[30] Wu, F., Wang, A., Liu, M., Wang, Q., Chen, J., Xia, S., et al. (2020) Neutralizing Antibody Responses to SARS-CoV-2 in a COVID-19 Recovered Patient Cohort and Their Implications. https://doi.org/10.1101/2020.03.30.20047365

[31] Duan, K., Liu, B., Li, C., Zhang, H., Yu, T., Qu, J., et al. (2020) Effectiveness of Convalescent Plasma Therapy in Severe COVID-19 Patients. Proceedings of the National Academy of Sciences of the United States of America, 117, 9490-9496. 


\section{Supplementary}

Supplementary Table S1. Web pages used to search SARS-CoV-2 immunoassays.

\begin{tabular}{|c|c|c|c|}
\hline Web page & Entity & Link & Number \\
\hline FIND & $\begin{array}{l}\text { FIND: Foundation for Innovative } \\
\text { New Diagnostics. A global } \\
\text { non-profit organization driving } \\
\text { innovation in the development } \\
\text { and delivery of diagnostics. }\end{array}$ & $\begin{array}{l}\text { https://www.finddx.org/covid-19/pipelin } \\
\text { e/?section=immunoassays\#diag_tab }\end{array}$ & 213 \\
\hline $\begin{array}{l}\text { Modern } \\
\text { Healthcare }\end{array}$ & $\begin{array}{l}\text { An independent American } \\
\text { publisher of national and regional } \\
\text { healthcare news. }\end{array}$ & $\frac{\text { https://www.modernhealthcare.com/safe }}{\text { ty/coronavirus-test-tracker-commerciall }}$ & 99 \\
\hline ISP-Chile & $\begin{array}{l}\text { Public Health Institute from the } \\
\text { Health Ministry-Chile }\end{array}$ & $\begin{array}{l}\text { https://www.minsal.cl/wp-content/uploa } \\
\text { ds/2020/04/Lista-assay-Rapidos-Covid-a } \\
\text { 1-03_04_2020.pdf }\end{array}$ & 12 \\
\hline FDA & $\begin{array}{l}\text { The Food and Drug } \\
\text { Administration (FDA or USFDA) } \\
\text { Federal agency of the United } \\
\text { States }\end{array}$ & $\begin{array}{l}\text { https://www.fda.gov/medical-devices/em } \\
\text { ergen- } \\
\text { cy-situations-medical-devices/faqs-diagn } \\
\text { ostic-assaving-sars-cov-2 }\end{array}$ & 54 \\
\hline
\end{tabular}

Supplementary Table S2. Complete list of assays and variables included in the study.

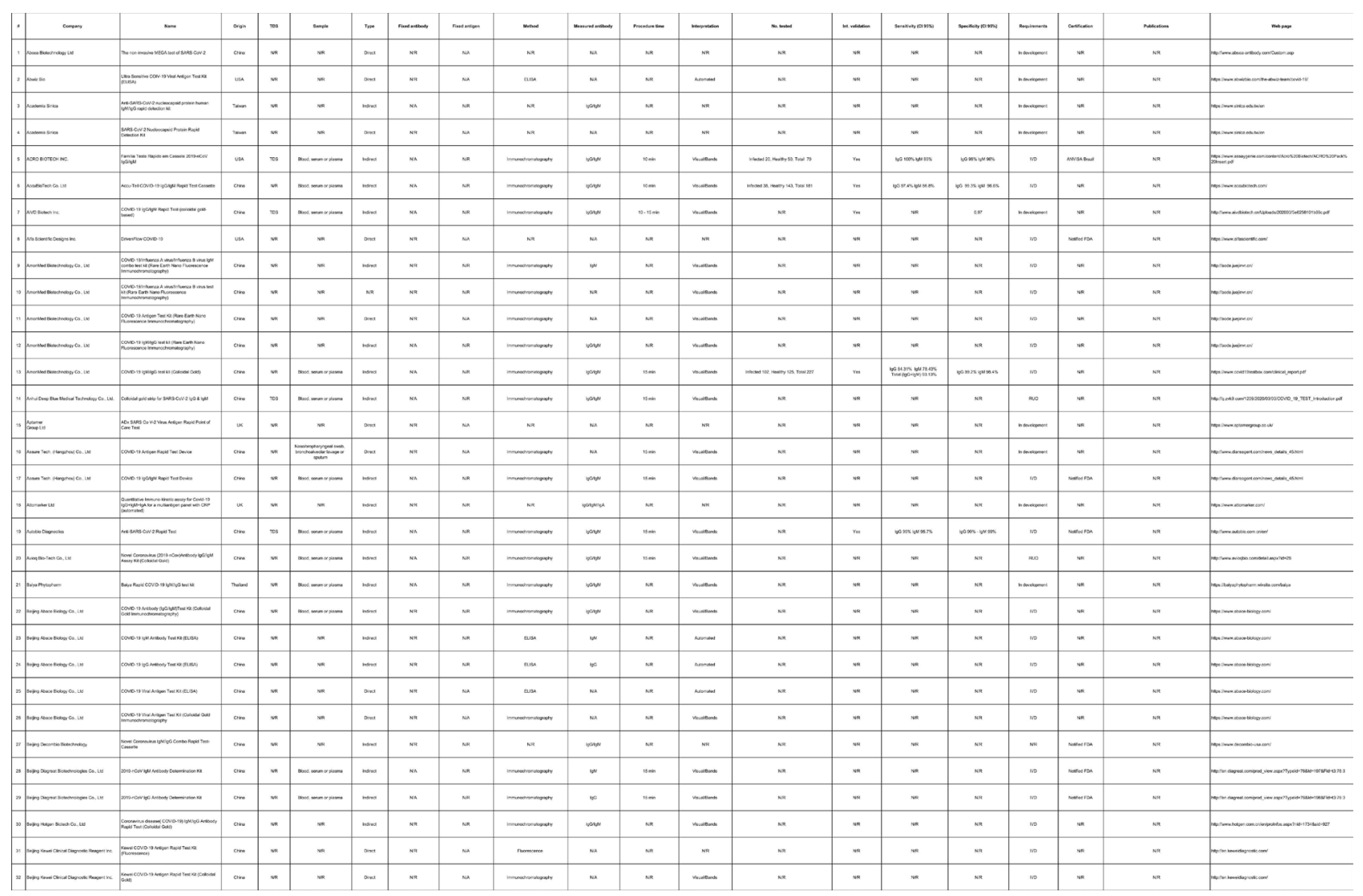




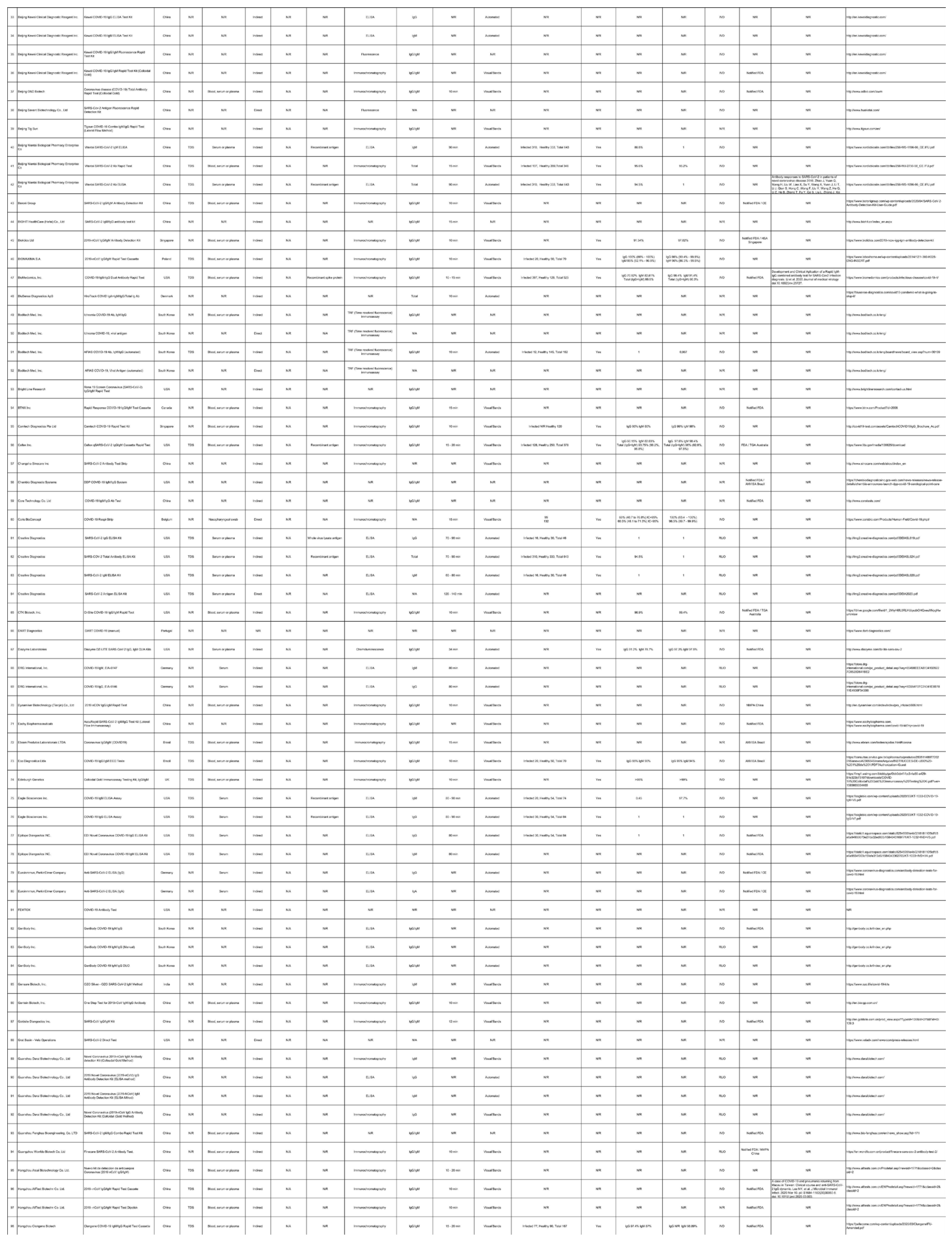




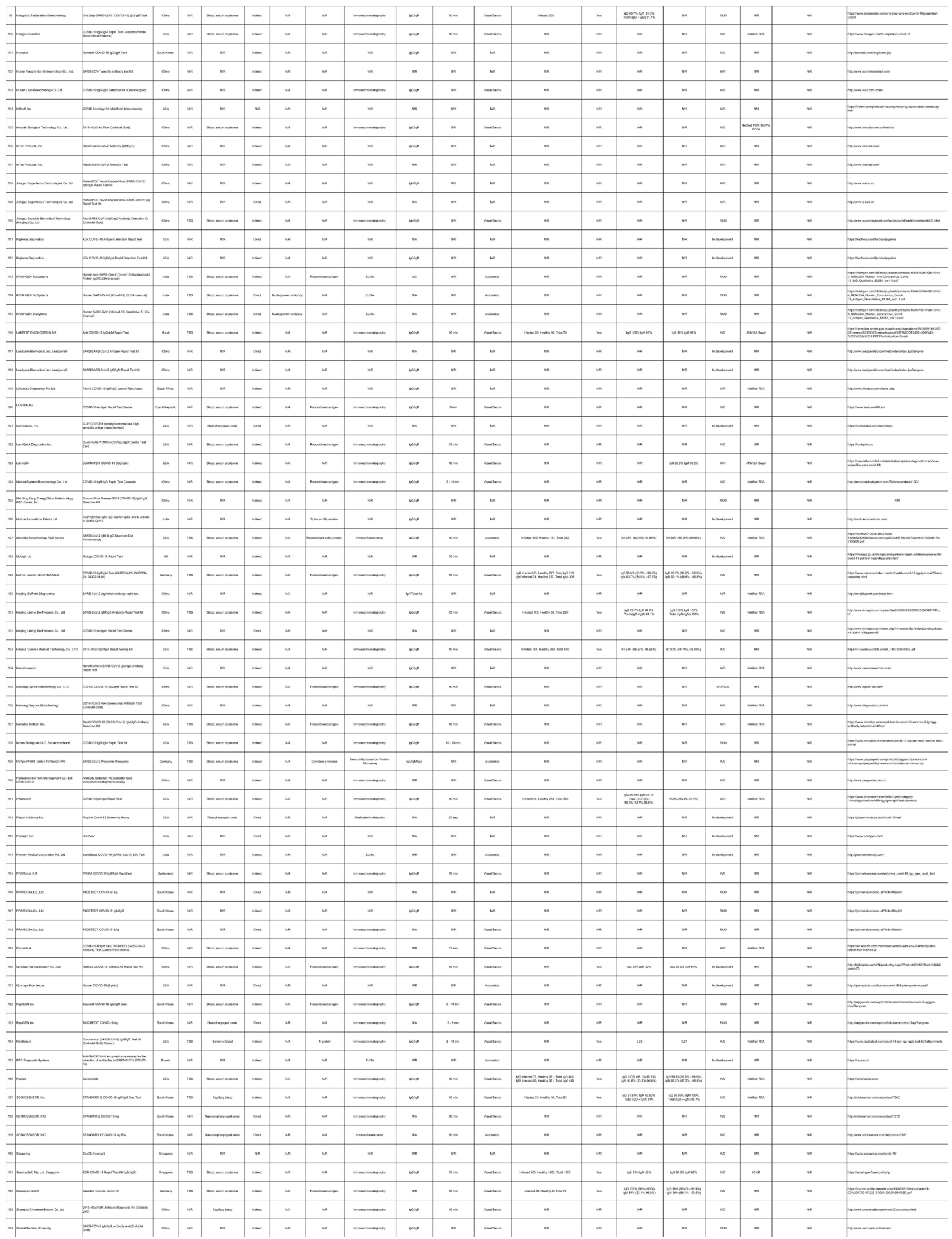




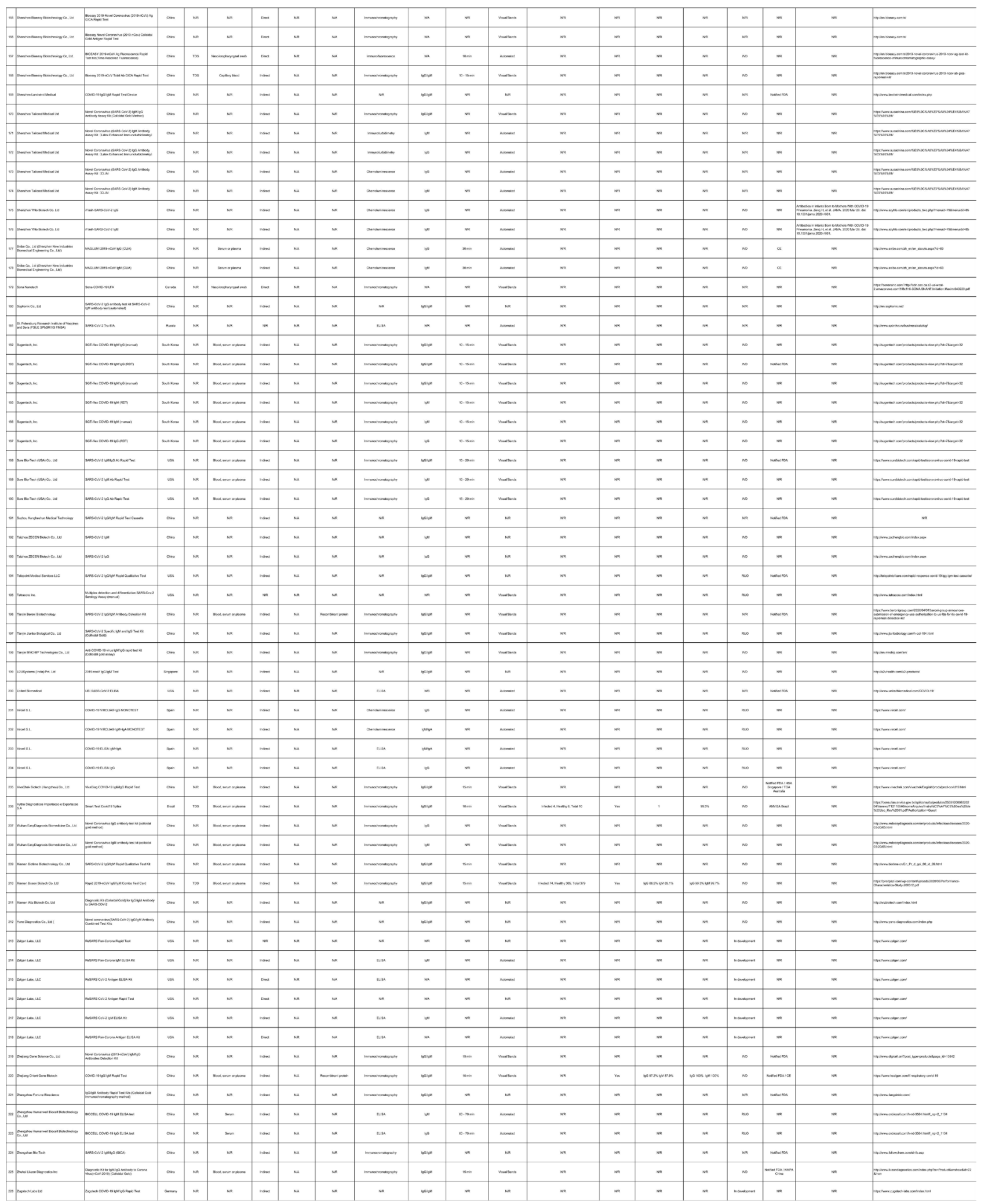




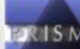

PRISMA 2009 Flow Diagram

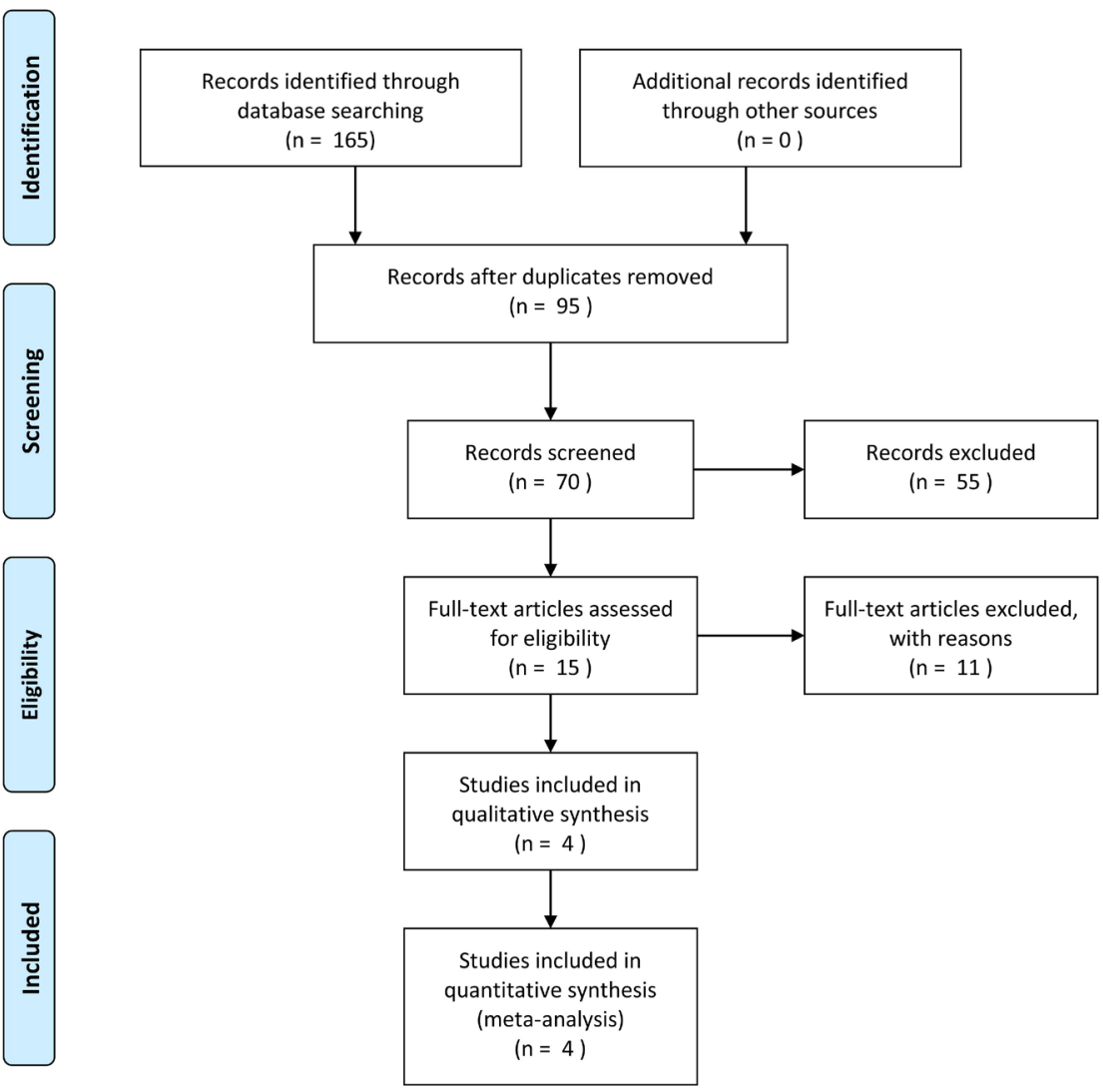

From: Moher D, Liberati A, Tetzlaff J, Altman DG, The PRISMA Group (2009). Preferred Reporting /tems for Systematic Reviews and MetaAnalyses: The PRISMA Statement. PLoS Med 6(7): e1000097. doi:10.1371/journal.pmed1000097

For more information, visit www.prisma-statement.org.

Supplementary Figure S1. Flow diagram of PRISMA statement. 